\title{
The assessment of the efficiency of the plant growth regulator "Cresolan" on grain crops
}

\author{
S.A. Ermakov, A.V. Mankov", L.A. Minukhin, Yu.R. Muratov, and A.E. Coparulina \\ Ural State Agrarian University, 620075 Yekaterinburg, Russia
}

\begin{abstract}
The article examines the regulators of plant growth and development, their properties and influence on living organisms. The new evaluated preparation with the trade name "Cresolan" was studied and tested at the central experimental field at the "Uralets", the educational farm of the Ural State Agrarian University. Various doses, periods, methods of use, combinations and its comparison with other similar preparations were studied (the experimental tests were carried out on spring wheat of the "Iren" variety and barley of the "Ecolog" variety). The spring wheat and barley plants showed great responsiveness to the preparation. According to the research results, a significant increase in the productivity and resistance of the studied grain crops was revealed, due to the increasing adaptive abilities of plants to the effects of unfavorable environmental factors. It was also concluded that it is necessary to generalize the material and to study some more issues for the development of an adapted technology of application of the plant growth and development regulator "Cresolan", which ensures stable efficiency.
\end{abstract}

\section{Introduction}

In modern agriculture such chemicals as fertilizers, herbicides, insect-fungicides are widely spread, and the most rational, economically profitable and environmentally friendly methods of their use are of great importance. Preparations with low consumption rates, rapid decompose without harmful metabolites take a large share [1-3].

A special place is occupied by the regulators of plant growth and development, capable of increasing their immunity to diseases, as well as adaptive properties to unfavorable environmental factors: high and low temperatures, lack of moisture, increased salinity, etc.

These preparations are grouped as adaptogens or resistance inductors. A number of such substances are known that are currently being produced and have industrial applications: humic preparations, mival, crezacin, ale, immunocytophyte, chitosan, silk, ambiol and others. Along with chemicals, microbiological preparations are also used: rizoplan, trichodermin, agate 25, pseudobacterin, etc. [4-9].

The proposed preparation has the following chemical formula - tris- (2-hydroxyethyl) ammonium-o-kresoxyacetate, the active ingredient is triethanolammonium salt of orthoresoxyacetic acid, the trade name is "Cresolan". It is an adaptogen of a broad spectrum, it increases the resistance of living organisms to a prolonged action of unfavorable factors: low

* Corresponding author: piap.kafedra@mail.ru 
and high temperatures, reduced oxygen content, aridity and many others. The peculiarity of this preparation is an increased content of the active substance, compared with its analogues (Krezacin).

"Cresolan" is completely harmless to humans and animals. The generally accepted indicator of toxicity LD50 is 3-10 g/ kg of live weight, depending on the administration route and the animal type. It does not have carcinogenic, teratogenic, gonadotoxic, embryotoxic, mutagenic and allergenic effects, and does not accumulate in the body.

"Cresolan" allows reduction or even abandon from traditional plant and animal protection products, additional dosing of fertilizers, antibiotics and other drugs. As ultra-small amounts of this preparation are used, we can talk about the transition to "the Green Food" technology. Due to the threat of the spread of viral infections among birds and a pandemic among other species, this drug can also be used to increase the immunity of farm animals.

The preparation "Cresolan" has passed extensive tests in the Republic of Bashkortostan, in the Kurgan and Orenburg regions, and it has shown high productivity and efficiency on potatoes, grains and vegetable crops. Their ability to increase the cold and heat resistance of plants, to stabilize the productivity of grain crops in extreme growing conditions has been confirmed [10].

The efficiency and productivity assessment of a new preparation, especially for grain crops, is the main goal of this research. The research results will be taken to develop recommendations for agricultural production.

\section{Materials and methods}

The weather conditions of the growing season were generally typical for the Sverdlovsk region: high heat supply and insufficient moisture, in some cases even aridity (Table 1).

High air temperatures were throughout June-July. But May and August differed in lower air temperatures in comparison with long-term data.

The growing season was characterized with an extremely uneven precipitation, the aridity of May and the first half of June was compensated with abundant rains in the second decade of June (up to $50 \mathrm{~mm}$ ), the next summer period had an acute shortage of precipitation (up to 50-70 mm). Precipitation shortage from the average long-term norm in the third decade of June was $70 \%$, in the second-third decade of July - 50-100\%, in August - 15$60 \%$.

Table 1. Agrometeorological indicators of the growing season of agricultural crops

\begin{tabular}{|c|c|c|c|c|c|}
\hline \multirow{2}{*}{ Months } & \multirow{2}{*}{ Decades } & \multicolumn{2}{|c|}{ Average air temperature, C } & \multicolumn{2}{c|}{ Precipitation, mm } \\
\cline { 3 - 6 } & & $\begin{array}{c}\text { Average long- } \\
\text { term }\end{array}$ & 2018 & $\begin{array}{c}\text { Average } \\
\text { long-term }\end{array}$ & 2018 \\
\hline May & 1 & 9,3 & 16,0 & 11 & 0 \\
\hline & 2 & 11,8 & 13,5 & 12 & 2 \\
\hline & 3 & 13,8 & 11,1 & 15 & 13 \\
\hline & per month & 11,6 & 13,5 & 38 & 15 \\
\hline June & 1 & 15,3 & 21,4 & 14 & 2 \\
\hline & 2 & 16,7 & 26,0 & 16 & 50 \\
\hline & 3 & 17,6 & 21,3 & 19 & 6 \\
\hline
\end{tabular}




\begin{tabular}{|c|c|c|c|c|c|}
\hline & per month & 16,5 & 22,9 & 46 & 58 \\
\hline July & 1 & 18,2 & 19,1 & 19 & 27 \\
\hline & 2 & 16,8 & 22,8 & 22 & 0 \\
\hline & 3 & 19,1 & 20,6 & 21 & 10 \\
\hline & per month & 18,0 & 20,8 & 62 & 37 \\
\hline August & 1 & 18,3 & 17,4 & 20 & 17 \\
\hline & 2 & 16,3 & 13,8 & 18 & 15 \\
\hline & 3 & 14,1 & 11,5 & 17 & 6 \\
\hline & per month & 16,2 & 14,2 & 55 & 38 \\
\hline
\end{tabular}

The hydrothermal coefficient (HTC) for a ten-degree period was 0.8 at a norm of 0.9 , for a 15-degree period was 0.75 (at a norm of 0.8 ).

Seed treatment with preparations was carried out before sowing in field experiments manually with the method of slurry treatment, the consumption of the working solution was $10 \mathrm{l} / \mathrm{t}$, the plants were sprayed in the booting phase with a knapsack sprayer and OP-2000 with the consumption of the working solution of $200 \mathrm{l} / \mathrm{ha}$. The working solution of the preparation was prepared immediately before the work. Harvesting was carried out in the phase of full ripeness of the grain with the Niva combine harvester.

The experiments were carried out on the central experimental field of the "Uralets" farm in the Beloyarsk region, the predecessors of the "Ecolog" barley variety and the "Iren" spring wheat variety were annual grasses. The seeding rate of wheat is 5 million germinating grains per hectare; barley is 4 million per hectare. The sowing date for spring wheat and barley is May 15.

\section{Results and discussion}

The research was carried out on spring wheat of the "Iren" variety and barley of the "Ecolog" variety in the Sverdlovsk region, at the central experimental field of the "Uralets", educational farm in the Beloyarsk region. Presowing seed treatment provided an increase in resistance to unfavorable environmental factors by $5-8.2 \%$ compared with control, an increase in productive tilling capacity and the number of grains in an ear.

The yield of the "Ecolog" barley increased by 2.9 centner/ ha $(6.8 \%)$ at the yield under control of 42.4 centner/ ha, the quality of grain became better, the weight of a thousand grains improved by 0.4 grams (Table 2). The yield of the "Iren" wheat increased by 5.8 centner/ ha (31\%) at the yield under control of 18.7 centner/ ha, the grain quality improved, the weight of a thousand grains increased by 2.1 grams (Table 2).

During the fieldwork it was found that the use of "Cresolan" reduced the extension of diseases, as a result the yield of grain crops increased. After treatment of the "Iren" wheat variety, the damage with brown leaf and stem rust did not show a significant effect, while the yield productivity increased by $1.5 \mathrm{c} /$ ha (Table 3 ). The development of leaf-stem spots at the "Ecolog" barley variety decreased by $9.1 \%$, while the yield increased by $2.2 \mathrm{c} /$ ha (Table 4). The damage with smut decreased by $1.5 \%$ compared to the control, while the yield productivity increased by $3.5 \mathrm{c} /$ ha (Table 5 ).

The analysis of the yield structure showed that the increase in productivity was due to the greater density of plants in the experimental variants, a denser productive stem, better 
grained ear and a grain size. Determination of the content and quality of gluten did not reveal a stable influence of "Cresolan" on these indicators.

\section{Conclusions}

1. "Cresolan" is, of course, a biologically active preparation that increases the adaptive capacity of plants to the effects of unfavorable environmental factors and increases the stability and productivity of grain crops.

2. A great responsiveness of spring wheat and barley plants to the preparation was revealed. 3. In order to develop a technology adapted to the local conditions for application of the plant growth and development regulator "Cresolan" which ensures stable efficiency, it is necessary to generalize the material and study the following issues:

- the reaction of various crops, varieties and seed material of a different quality to the "Cresolan" preparation;

- the effectiveness of the growth regulator "Cresolan" at different backgrounds of nutrition and weediness levels;

- compatibility with seed disinfectants, fungicides and herbicides and possibilities, in this case, of reducing the consumption rates of chemical plant protection agents.

Table 2. The influence of the "Cresolan" preparation on the yield of the "Ecolog" barley variety and its structure, the educational farm "Uralets", the Beloyarsk region

\begin{tabular}{|c|c|c|c|c|c|c|c|}
\hline \multirow{2}{*}{$\begin{array}{c}\text { Experimenth } \\
\text { options }\end{array}$} & \multirow{2}{*}{$\begin{array}{l}\text { Number of } \\
\text { plants be- } \\
\text { fore har- } \\
\text { vesting, pcs } \\
\quad / \mathrm{m}^{2}\end{array}$} & \multirow{2}{*}{$\begin{array}{l}\text { Number of } \\
\text { productive } \\
\text { stems, } \\
\text { pcs } / \mathrm{m}^{2}\end{array}$} & \multirow{2}{*}{$\begin{array}{l}\text { Weight } \\
\text { of } 1000 \\
\text { grains, } g\end{array}$} & \multicolumn{2}{|c|}{ Ear } & \multirow{2}{*}{$\begin{array}{c}\text { Average } \\
\text { yield, c / } \\
\text { ha }\end{array}$} & \multirow{2}{*}{$\begin{array}{c}+,- \\
\text { to the } \\
\text { control, } \\
\text { c/ha }\end{array}$} \\
\hline & & & & $\begin{array}{l}\text { Number } \\
\text { of ears, } \\
\text { pcs. }\end{array}$ & $\begin{array}{c}\text { Number } \\
\text { of } \\
\text { grains, } \\
\text { pcs. }\end{array}$ & & \\
\hline Control & 509 & 576 & 46,8 & 12 & 15,4 & 42,4 & - \\
\hline $\begin{array}{l}\text { Cresolan } 4 \\
\mathrm{~g} / \mathrm{t}\end{array}$ & 480 & 625 & 47,2 & 15 & 15,8 & 45,3 & $+2,9$ \\
\hline
\end{tabular}

Table 3. The influence of the "Cresolan" preparation on the yield of the "Iren" spring wheat variety and its structure, the educational farm "Uralets", the Beloyarsk region

\begin{tabular}{|c|c|c|c|c|c|c|c|}
\hline \multirow{2}{*}{$\begin{array}{l}\text { Experiment } \\
\text { options }\end{array}$} & \multirow[b]{2}{*}{$\begin{array}{l}\text { Number of } \\
\text { plants be- } \\
\text { fore har- } \\
\text { vesting, pcs } \\
\quad / \mathrm{m}^{2}\end{array}$} & \multirow{2}{*}{$\begin{array}{c}\text { Number of } \\
\text { productive } \\
\text { stems, } \\
\text { pcs } / \mathrm{m}^{2}\end{array}$} & \multirow{2}{*}{$\begin{array}{l}\text { Weight } \\
\text { of } 1000 \\
\text { grains, } g\end{array}$} & \multicolumn{2}{|c|}{ Ear } & \multirow{2}{*}{$\begin{array}{c}\text { Average } \\
\text { yield, c / } \\
\text { ha }\end{array}$} & \multirow{2}{*}{$\begin{array}{c}+,- \\
\text { to the } \\
\text { control, } \\
\text { c/ha }\end{array}$} \\
\hline & & & & $\begin{array}{c}\text { Number } \\
\text { of ears, } \\
\text { pcs. }\end{array}$ & $\begin{array}{l}\text { Number } \\
\text { of } \\
\text { grains, } \\
\text { pcs. }\end{array}$ & & \\
\hline Control & 225 & 304 & 20,8 & 12,3 & 20,6 & 18,7 & - \\
\hline $\begin{array}{l}\text { Cresolan } 4 \\
\mathrm{~g} / \mathrm{t}\end{array}$ & 240 & 345 & 22,9 & 13,7 & 24,3 & 24,5 & $+5,8$ \\
\hline
\end{tabular}

Table 4. The comparative effectiveness of the "Cresolan" preparation on the spring wheat "Iren", the educational farm "Uralets", the Beloyarsk region

\begin{tabular}{|c|c|c|c|c|}
\hline Options & $\begin{array}{c}\text { Damage with brown } \\
\text { leaf rust, \% }\end{array}$ & $\begin{array}{c}\text { Stem rust } \\
\text { damage, } \%\end{array}$ & \multicolumn{2}{|c|}{ Productivity } \\
\cline { 4 - 5 } & & & $\mathrm{c} / \mathrm{ha}$ & $\begin{array}{c}+,- \\
\text { to the con- } \\
\text { trol, c/ha }\end{array}$ \\
\hline Control & 20 & 10 & 22,3 & - \\
\hline $\begin{array}{c}\text { Spring wheat (Cresolan } \\
4 \mathrm{~g} / \mathrm{t} \text { ) }\end{array}$ & 20 & 10 & 23,8 & $+1,5$ \\
\hline
\end{tabular}


Table 5. The development of leaf spots and the productivity of the "Ecolog" barley variety when treated with Cresolan, the educational farm "Uralets", the Beloyarsk region

\begin{tabular}{|l|c|c|c|}
\hline \multicolumn{1}{|c|}{ Option } & $\begin{array}{c}\text { Development of leaf- } \\
\text { stem spots, \% }\end{array}$ & $\mathrm{c} / \mathrm{ha}$ & \begin{tabular}{c} 
Productivity \\
\cline { 3 - 4 }
\end{tabular} \\
\cline { 3 - 4 } & 21,2 & 16,3 & - \\
\hline Control & 12,1 & 18,5 & $+2,2$ \\
\hline Cresolan $10 \mathrm{~g} / \mathrm{ha}^{*}$ & &
\end{tabular}

* Spraying plants with preparations in the phase of barley entering the tube

Table 6. The influence of the "Cresolan" preparation on the reduction of smut infestation and the productivity of the "Ecolog" barley variety, the educational farm "Uralets", the Beloyarsk region

\begin{tabular}{|l|c|c|c|c|}
\hline \multirow{2}{*}{ Option } & \multicolumn{2}{|c|}{ Smut infestation } & \multicolumn{2}{c|}{ Productivity } \\
\cline { 2 - 5 } & $\%$ & $\begin{array}{c}+,- \\
\text { to the control }\end{array}$ & $\mathrm{c} / \mathrm{ha}$ & $\begin{array}{c}+,- \\
\text { to the control, } \mathrm{c} / \mathrm{ha}\end{array}$ \\
\hline Control & 4,7 & - & 15,7 & - \\
\hline Cresolan $4 \mathrm{~g} / \mathrm{t}$ & 3,2 & $-1,5$ & 19,2 & $+3,5$ \\
\hline
\end{tabular}

\section{References}

1. V.A. Kasparov, V.K Promonenkov, The use of pesticides abroad (M.: Agropromizdat, 1990)

2. O.A. Shapoval, V.V. Vakulenko, I.P. Mozharova, Plant protection and quarantine, 3, (2011)

3. V.V. Vakulenko, Plant protection and quarantine, 2 (2014)

4. O.A. Shapoval, I.P. Mozharova, A.Ya. Barchukova, Plant growth regulators in agricultural technologies of major agricultural crops (VNIIA Moscow, 2015)

5. O.G. Sinyashin, O.A. Shapoval, M.M. Shulayeva, Plodorodiye, 5, 92 (2016)

6. N.Yu. Petrov, N.A. Petrova, S.V.Golub, Izvestiya NV AUK, 1 (2009)

7. V.G. Sychev, O.A. Shapoval, I.N. Mozharova, T.M. Verevkina, M.T. Mukhina Guidelines for registration testing of plant growth regulators, defoliants and desiccants in agriculture, Production-practical edition (M.: FGBNU, Rosinformafotekh, 2016)

8. Ruijun Qin, Christos Noulas, Don Wysocki, Xi Liang, Guojie Wang, Scott Lukas, Agriculture, 10(7), 305 (2020)

9. N. Khan, A.M.D. Bano, A. Babar, PLoS ONE, 15(4), e0231426 (2020)

10. S.A. Yermakov, A.A. Yermakov, A.A. Titov, Cresolan - plant growth regulator, Materials of the All-Russian Scientific and Practical Conference with International Participation, Modern approaches and methods in plant protection, 22-23 (2018) 